to normal or near normal levels within $4-8$ weeks, and the clinical and histological findings improved 3-12 months after therapy. The pre-treatment duration of $\mathrm{CAH}$ (median 2 years in responders $v s 10$ years in non-responders) influences the outcome of therapy significantly $(p=0.05)$. Patients without HBV sequences integrated into the hepatocyte genome tended to have a better response to therapy. In the control group of 10 untreated patients only one spontaneous remission occurred, in a 41 -year-old woman. In contrast to Alexander et al's study no attempts were made to stratify or match any variables to identify pretreatment factors affecting therapy outcome.

Since the responder rates of the IFN- $\alpha$ and our trial (6/23 and $5 / 10$, respectively, for loss of $\mathrm{HBeAg}$ ) greatly exceeded the spontaneous seroconversion rates $(0 / 23$ and $1 / 10)$ but do not differ significantly from each other, we propose consideration of the IFN- $\beta$ and IFN- $\gamma$ combination, given the advantage of a shorter treatment duration, for a larger trial.

Department of Virus Research,

Max-Planck-Institut fur Biochemie,

8033 Martinsried,

Munich, West Germany

W. H. CASElmanN

P. H. HOFSCHNEIDER

R. KosHY

Department of Internal Medicine,

Krankenhaus der Barmherzigen Brider,

Munich

J. EISENBURG

1. Caselmann WH, Eisenburg J, Hofschneider PH, Koshy R. Antiviral therapy of chronic-active hepatitis $B$ with interferon-beta and interferon-gamma: a controlled trial. 7 Med Virol 1987; 21: A128 (abstr).

\section{HBV/HDV COINFECTION}

SIR,-We do not agree with Dr DeCock and colleagues (June 20, $\mathrm{p}$ 1438) that the long-term prognosis of acute hepatitis in patients simultaneously infected by the hepatitis $B$ virus (HBV) and the hepatitis delta virus (HDV) is always good. The possible chronic evolution of $\mathrm{HDV}$ infection and disease in cases of $\mathrm{HBV} / \mathrm{HDV}$ coinfection has been reported by us $^{1}$ and independently by Amoroso et al. ${ }^{2}$ Chronic hepatitis developed in 6 of $220(2 \cdot 7 \%)$ drug addicts admitted to our unit and prospectively studied during 1979-86 after apparently acute HBV/HDV coinfection. These 6 patients were males, aged 18 to 25 . None had had clinical hepatitis before. On admission they were $\mathrm{HBsAg}$ and $\mathrm{HBeAg}$ positive, and had high titres (over 1:4000) of IgM anti-HBc. A transient HD antigenaemia was detected in 3 patients. In all the cases IgM and IgG anti-HD became detectable in rising titres during the following weeks. The 6 patients remained HBsAg positive during follow-up (mean 26 [SD 10] months, range 17-42), and IgM and IgG anti-HD remained positive at titres ranging from $10^{-2}$ to $10^{-5}$. In all the patients alanine aminotransferase (ALT) levels have remained high. A progressive liver disease (4 chronic active hepatitis and 2 active cirrhosis) was established just 5 to 18 months after the acute episode. It also seems unlikely that the severity of hepatitis prevents its chronicity, since 2 of our 6 patients had a severe illness (prothrombin activity less than half normal).

In addition, as far as the pathogenesis of the double bout of hepatitis in HBV/HDV coinfected patients is concerned, we do not agree with DeCock and colleagues that the temporarily related appearance of anti-HD antibody to the second peak of ALT suggests that relapse is caused by HDV-induced hepatocellular necrosis. In fact we have not observed a correlation between the appearance of anti-HD antibodies and the second bout of ALT (table). Furthermore, a transient HD antigenaemia generally can be detected only during the first ALT elevation, coincident with the presence of HDAg in the liver. According to the currently available

SEROLOGICAL HDV MARKERS IN HBV/HDV COOINFECTED PATIENTS WITH A BIPHASIC COURSE OF THE ACUTE DISEASE

\begin{tabular}{|c|c|c|c|c|}
\hline \multirow[b]{2}{*}{$\begin{array}{l}\text { HDAg on } \\
\text { admission }\end{array}$} & \multirow[b]{2}{*}{ No } & \multicolumn{3}{|c|}{ Time of detection of total anti-HD antibodies } \\
\hline & & $\begin{array}{l}\text { Before } 2 \text { nd peak } \\
\text { of ALT }\end{array}$ & $\begin{array}{l}\text { Coincident with } \\
\text { 2nd peak of AIT T }\end{array}$ & $\begin{array}{l}\text { After 2nd peak } \\
\text { of ALT }\end{array}$ \\
\hline $\begin{array}{l}\text { Positive } \\
\text { Negative }\end{array}$ & $\begin{array}{l}10 \\
25\end{array}$ & $\begin{array}{r}2 \\
11\end{array}$ & $\begin{array}{l}1 \\
1\end{array}$ & $\begin{array}{r}7 \\
13\end{array}$ \\
\hline Total & 35 & $13(37 \%)$ & $2(6 \%)$ & $20(57 \%)$ \\
\hline
\end{tabular}

data that HDV is a cytopathic virus it can be assumed that the first enzyme peak is because of HDV-induced liver necrosis. Whether the second bout of hepatitis is caused by the immune response to a restored synthesis of $\mathrm{HBV}$ gene products after the acute phase of HDV hepatitis ${ }^{3}$ remains speculative.

Finally, DeCock et al ask how long total anti-HD antibodies persist after self-limited HBV/HDV coinfection. Our data on 68 parenteral drug abusers in whom this antibody response was prospectively evaluated show persistence for a mean (SD) period of $9.7(6.2)$ months after the acute episode $(6.7$ [5.5] months after the clearance of $\mathrm{HBsAg}$ ).

Institute of Intemal Medicine,

Infectious Diseases,

and Immunopathology,

Ospedale L Sacco,

20157 Milan, Italy

Francesco CaREDda SPINELLO ANTINORI Carla Pastecchia MAURO MORONI

1. Caredda F, Antinon S, Re T, Pastecchia C, Moroni M. Course and prognosis of acute HDV hepatitis. Prog Clin Biol Res 1987; 234: 267-76.

2. Amoroso $P$, Giorgio A, Fico $P$, et al. Delta infection in the Naples area: Epidemiologic and clinical significance. $\mathcal{F}$ Hepatol 1986; 2: 11-18.

3. Bonino F, Smedile A. Delta agent (type D) hepatitis. Semin Liver Dis 1986; 6: 28-33.

\section{EFFECT OF ACTIVATED CHARCOAL ON HYPERCHOLESTEROLAEMIA}

SIR,-A decrease in plasma total cholesterol and low density lipoprotein cholesterol after treatment with activated charcoal was described in patients with hypercholesterolaemia by Kuusisto et al. ${ }^{1}$ Their results contrast with data that we obtained in a double-blind trial in mainly primary hyperlipidaemic patients. In the first part of the trial 12 patients were randomised to receive either $15 \mathrm{~g}$ activated $(n=6)$ or $15 \mathrm{~g}$ non-activated charcoal in granulated form as placebo $(n=6)$ over 12 weeks. In the second part the same patients were randomised again to receive either $30 \mathrm{~g}$ activated $(\mathrm{n}=6)$ or $30 \mathrm{~g}$ non-activated $(n=6)$ charcoal. Mean serum cholesterol levels in patients treated with activated charcoal did not decrease significantly (table). In both groups during treatment with activated charcoal, 1 patient had a significant decrease in serum cholesterol level. No decrease in serum triglycerides was observed in 3 hypertriglyceridaemic patients.

EFFECT OF 12 WEEKS' TREATMENT WITH ACTIVATED CHARCOAL ONN SERUM CHOLËS̄TEROL LEVEL' (M̄EAN, SD)

\begin{tabular}{l|c|c}
\hline \multirow{2}{*}{ Treatment (g) } & \multicolumn{2}{|c}{ Serum cholesterol (mmol/1) } \\
\cline { 2 - 3 } \multicolumn{1}{c|}{ Activated charcoal: } & $10.5(2 \cdot 2)$ & After treatment \\
15 & $10.5(1 \cdot 5)$ & $9 \cdot 7(2 \cdot 7)$ \\
30 & $10.8(1 \cdot 9)$ & $9 \cdot 7(1.6)$ \\
Placebo: & $11.9(2 \cdot 3)$ & $11 \cdot 0(2 \cdot 6)$ \\
15 & $11.5(2 \cdot 7)$ \\
\hline 30 &
\end{tabular}

The contrasting findings of Kuusisto et al may be due to the non-placebo design of their study. It may also be that there are responders and non-responders in treating hypercholesterolaemia with activated charcoal.

Diakonessenhuis

PO Box 80250,

3508 TG Utrecht, The Netherlands;

and University Hospital,

Urrecht

J. B. L. HOEKSTRA

D. W. ERKELENS

1. Kuusisto P, Vapaatalo H, Manninen V, Huttunen JK, Neuvonen PJ. Effect of activated charcoal on hypercholesterolaemia. Lancet 1986; ii: 366-67.

\section{POSTOPERATIVE CARDIAC DEATH}

SiR,-Your July 11 editorial on postoperative cardiac death ignores a contributory factor that is probably important, namely the inadvertent abrupt withdrawal of cardiac drugs in many patients admitted for surgery. Duthie et $a^{1}$ reported that $29 \%$ of patients taking cardiovascular drugs as outpatients failed to have their 